\title{
Biogenesis and Intranuclear Trafficking of Human Box C/D and H/ACA RNPs
}

\author{
T. KISS, ${ }^{* \dagger}$ E. FAYET, ${ }^{*}$ B.E. JÁdy, ${ }^{*}$ P. RICHARD, ${ }^{*}$ AND M. WEBER* \\ *Laboratoire de Biologie Moléculaire Eucaryote du CNRS, UMR5099, IFR109, 31062 Toulouse, France; \\ Biological Research Center, Hungarian Academy of Sciences, Szeged, Hungary
}

\begin{abstract}
Box C/D and H/ACA snoRNAs represent two abundant groups of small noncoding RNAs. The majority of box C/D and H/ACA snoRNAs function as guide RNAs in the site-specific 2'-O-methylation and pseudouridylation of rRNAs, respectively. The box C/D snoRNAs associate with fibrillarin, Nop56, Nop58, and 15.5K/NHPX proteins to form functional snoRNP particles, whereas all box H/ACA snoRNAs form complexes with the dyskerin, Nop10, Nhp2, and Gar1 snoRNP proteins. Recent studies demonstrate that the biogenesis of mammalian snoRNPs is a complex process that requires numerous trans-acting factors. Most vertebrate snoRNAs are posttranscriptionally processed from pre-mRNA introns, and the early steps of snoRNP assembly are physically and functionally coupled with the synthesis or splicing of the host pre-mRNA. The maturing snoRNPs follow a complicated intranuclear trafficking process that is directed by transport factors also involved in nucleocytoplasmic RNA transport. The human telomerase RNA (hTR) carries a box H/ACA RNA domain that shares a common Cajal-body-specific localization element with a subclass of box H/ACA RNAs, which direct pseudouridylation of spliceosomal snRNAs in the Cajal body. However, besides concentrating in Cajal bodies, hTR also accumulates at a small, structurally distinct subset of telomeres during S phase. This suggests that a cell-cycle-dependent, dynamic localization of hTR to telomeres may play an important regulatory role in human telomere synthesis.
\end{abstract}

The mammalian nucleus contains many small nuclear RNAs (snRNAs) that can be grouped under two main classes based on their intranuclear localization (for review, see Yu et al. 1999). Early cell fractionation experiments revealed that the abundant $\mathrm{U} 1, \mathrm{U} 2, \mathrm{U} 4, \mathrm{U} 5$, and U6 snRNAs localize to the nucleoplasm, whereas another abundant snRNA, U3, was found to copurify with the nucleoli and, therefore, it was designated as small nucleolar RNA (snoRNA) (Reddy et al. 1981). Later, it turned out that the U3 snoRNA represents the founding member of a major class of small noncoding RNAs that reside in the nucleolus, share the evolutionarily conserved C (RUGAUGA) and D (uCUGA) box motifs, and associate with a nucleolar protein, fibrillarin (Fig. 1) (Tyc and Steitz 1989).

In the early 1990s, three novel human snoRNAs, U17, $\mathrm{E} 2$, and $\mathrm{E}$ 3, which lacked $\mathrm{C}$ and $\mathrm{D}$ boxes and did not associate with fibrillarin, were discovered (Kiss and Filipowicz 1993; Ruff et al. 1993). Later, construction and characterization of a cDNA library of human nucleolar RNAs presented further examples of mammalian snoRNAs lacking C and D boxes (Ganot et al. 1997b). In vitro structure probing experiments, followed by structural comparisons with yeast snoRNAs, revealed that all snoRNAs devoid of $\mathrm{C}$ and $\mathrm{D}$ boxes share the conserved box H (AnAnnA) and ACA motifs and fold into a common "hairpin-hinge-hairpin-tail" secondary structure, demonstrating that they constitute a novel, evolutionarily conserved class of snoRNAs (Fig. 1) (Balakin et al. 1996; Kiss et al. 1996; Ganot et al. 1997b).

In the past years, several hundreds of box $\mathrm{C} / \mathrm{D}$ and H/ACA snoRNAs have been identified in a broad variety of organisms (for review, see Bachellerie et al. 2002; Hüttenhofer et al. 2005). For a compilation of vertebrate
snoRNAs, see http://www-snorna.biotoul.fr/index.php (Lestrade and Weber 2006). We learned that both box C/D and H/ACA snoRNA families show a high structural and functional conservation from humans to Archaea (for review, see Terns and Terns 2002; Omer et al. 2003; Bertrand and Fournier 2004; Tran et al. 2004). The majority of box C/D snoRNAs function as guide RNAs in the site-specific 2'-O-methylation of rRNAs (Cavaillé et al. 1996; Kiss-László et al. 1996), whereas most box H/ACA snoRNAs direct pseudouridylation of rRNAs (Fig. 1) (Ganot et al. 1997a; Ni et al. 1997). The box $\mathrm{C} / \mathrm{D}$ and $\mathrm{H} / \mathrm{ACA}$ modification guide snoRNAs function in the form of snoRNPs. The box C/D snoRNAs are associated with four box C/D snoRNP proteins, fibrillarin, Nop56, Nop58, and 15.5K/NHPX (Fig. 1) (Schimmang et al. 1989; Tyc and Steitz 1989; Wu et al. 1998; Lafontaine and Tollervey 1999; Newman et al. 2000; Watkins et al. 2000). The box H/ACA snoRNAs form snoRNP complexes with dyskerin, Nhp2, Nop10, and Gar1 proteins (Balakin et al. 1996; Ganot et al. 1997b; Henras et al. 1998; Watkins et al. 1998; Lyman et al. 1999). Both box C/D and H/ACA guide RNAs select the substrate nucleotides for modification through forming transient base-pairing interactions with complementary rRNA sequences. The associated snoRNP proteins, fibrillarin and dyskerin, catalyze the 2'-O-methyl transfer and the uridine-to-pseudouridine isomerization reactions, respectively (Wang et al. 2000; Hoang and Ferre-D'Amare 2001).

Besides directing rRNA modification, the box $\mathrm{C} / \mathrm{D}$ and H/ACA guide RNPs also function in methylation and pseudouridylation of spliceosomal snRNAs and other cellular RNAs, including some tRNAs and mRNAs. The 


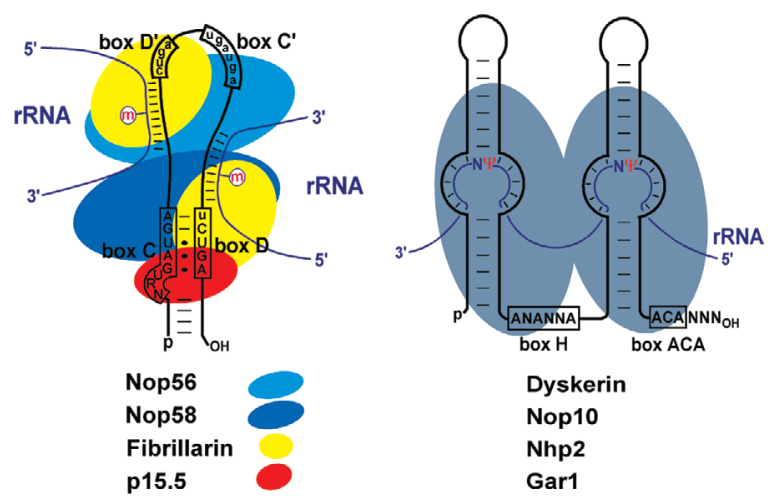

Figure 1. Schematic structure of box C/D 2'-O-methylation and box H/ACA pseudouridylation guide snoRNPs. Black lines represent snoRNA sequences. Positions and consensus sequences of the conserved $\mathrm{C}$ and $\mathrm{D}$ boxes and the related $\mathrm{C}^{\prime}$ and $\mathrm{D}^{\prime}$ boxes as well as the $\mathrm{H}$ and ACA boxes are shown. Blue lines indicate pre-rRNA sequences interacting with the antisense elements of box $\mathrm{C} / \mathrm{D}$ and H/ACA guide RNAs. The 2'-O-methylated nucleotides located five nucleotides upstream of the $\mathrm{D}$ or $\mathrm{D}^{\prime}$ box sequences are indicated $(m)$. The uridine residues selected for pseudouridylation are shown ( $\Psi)$. Binding of the $15.5 \mathrm{~K}$ (NHPX) protein to the terminal Kink-turn motif of box C/D snoRNAs is a prerequisite for recruitment of the two highly related proteins Nop56 and Nop58 and two copies of the methyltransferase, fibrillarin (Cahill et al. 2002; Watkins et al. 2002). Organization of box H/ACA snoRNP proteins is still unknown. Electron microscopy images of purified yeast snR30 box H/ACA snoRNP particles showed a highly symmetric bipartite structure, suggesting that two sets of the four box H/ACA snoRNP core proteins dyskerin, Nop10, Nhp2, and Gar1 bind to the 5'- and $3^{\prime}$ hairpins of snR30 (Watkins et al. 1998). interested reader may consult several recent reviews on the structure, function, and evolution of box C/D and H/ACA RNPs (Kiss 2001; Bachellerie et al. 2002; Filipowicz and Pogacic 2002; Terns and Terns 2002; Decatur and Fournier 2003; Bertrand and Fournier 2004; Henras et al. 2004; Dennis and Omer 2005). Here, we focus on recent advances concerning the biogenesis and intranuclear trafficking of mammalian box $\mathrm{C} / \mathrm{D}$ and H/ACA snoRNPs, including the human telomerase H/ACA RNP.

\section{SPLICING-DEPENDENT ASSEMBLY OF INTRONIC BOX C/D SNORNPS}

In vertebrates, the great majority of box $\mathrm{C} / \mathrm{D}$ and H/ACA snoRNAs are encoded within introns of premRNAs (Fig. 2) (Leverette et al. 1992; Fragapane et al. 1993; Kiss and Filipowicz 1993; Tycowski et al. 1993). Normally, the mature intronic snoRNAs are processed from the removed and debranched host introns by $5^{\prime}$ to $3^{\prime}$ and $3^{\prime}$ to $5^{\prime}$ exonucleolytic activities (Tycowski et al. 1993; Kiss and Filipowicz 1995; Cavaillé and Bachellerie 1996; Watkins et al. 1996). Therefore, splicing of the host pre-mRNA is essential for providing linear precursor snoRNA substrates for the processing exonucleases (Ooi et al. 1998). Consistent with a splicing-mediated precursor snoRNA release, all host introns for vertebrate snoRNAs encode only a single intronic snoRNA (the one intron/one snoRNA rule). The biosynthesis of functional intronic box C/D

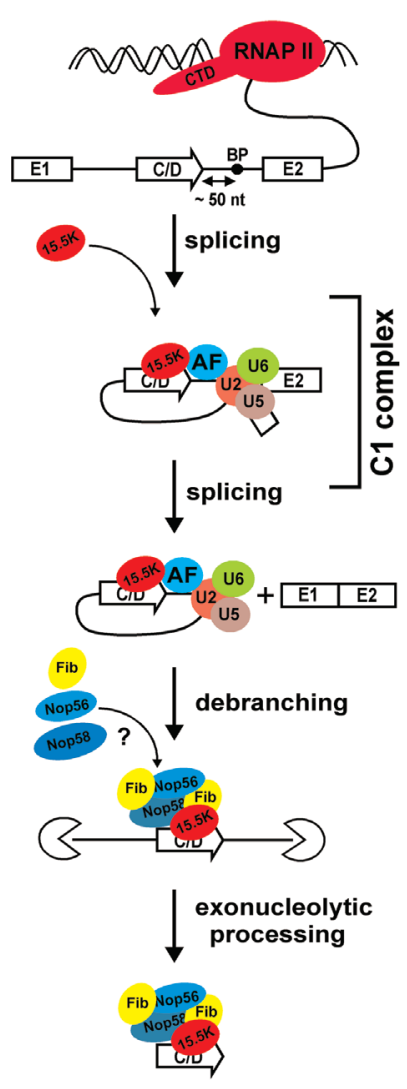

box H/ACA
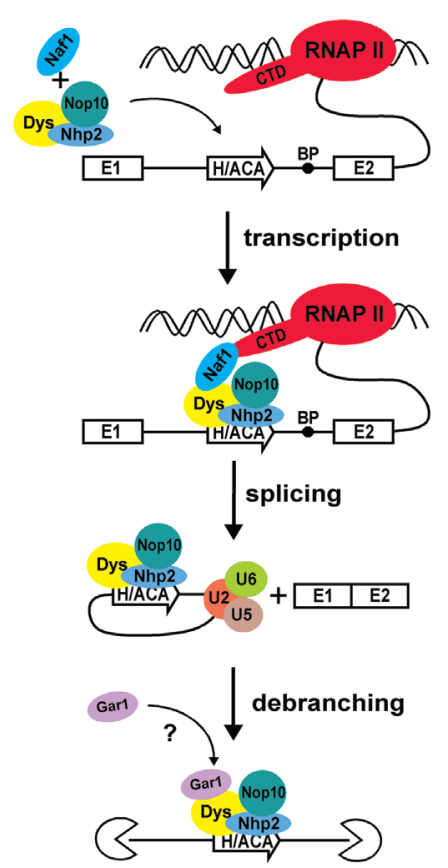

$\downarrow \begin{gathered}\text { exonucleolytic } \\ \text { processing }\end{gathered}$

Figure 2. Models for splicing- and transcriptiondependent assembly of mammalian intron-encoded snoRNPs. The great majority of mammalian box $\mathrm{C} / \mathrm{D}$ and H/ACA snoRNAs are processed from pre-mRNA introns. Whereas most box C/D snoRNAs are located about 50 nucleotides upstream of the branch point (BP), box H/ACA snoRNAs possess a random location relative to the $5^{\prime}$ and $3^{\prime}$ splice sites. Recognition of intronic box C/D snoRNA sequences occurs at a relatively late step of host pre-mRNA splicing. A putative assembly factor (AF) that likely interacts with splicing factors associated with the BP region of the host pre-mRNA facilitates the recruitment of the $15.5 \mathrm{~K} / \mathrm{NHPX}$ box C/D snoRNP protein to the Kinkturn motif of the intronic snoRNA. Assembly of box H/ACA snoRNPs already occurs during pre-mRNA synthesis. The Naf1 protein may promote cotranscriptional recruitment of the dyskerin/Nop10/Nhp2 protein complex to the nascent H/ACA snoRNA through forming specific interactions with both dyskerin and the CTD of RNAP II. Binding of Nop56, Nop58, and fibrillarin box C/D and Gar1 box $\mathrm{H} / \mathrm{ACA}$ snoRNP proteins is believed to occur in the Cajal body. For other details, see the text. 
snoRNPs includes the ordered recruitment of the four box C/D (fibrillarin, Nop56, Nop58, and 15.5K/NHPX) or box H/ACA (dyskerin, Nhp2, Nop10, and Gar1) snoRNP proteins. Binding of snoRNP proteins is essential for the correct processing and metabolic stability of the mature snoRNA, since the associated snoRNP proteins define the termini of the snoRNA by protecting them from the processing exonucleases. However, normally, mammalian pre-mRNA introns are rapidly degraded after splicing (Padgett et al. 1986). The rapid intron turnover may facilitate the recycling of ribonucleotides and splicing factors bound to the removed intron lariat (Green 1991). Therefore, efficient intronic snoRNA expression might require an active mechanism that recruits snoRNP proteins to the nascent snoRNA already during synthesis or splicing of the host pre-mRNA.

The $5^{\prime}$ and $3^{\prime}$ terminal regions of box C/D snoRNAs encompassing the box $\mathrm{C}$ and $\mathrm{D}$ sequences, respectively, fold into a stem-internal loop-stem structure, called the Kink-turn (Fig. 1) (Watkins et al. 2000; Klein et al. 2001). The noncanonical G-A, A-G, and U-U base pairs formed by conserved nucleotides in the $\mathrm{C}$ and $\mathrm{D}$ box motifs are important for the establishment of a functional Kink-turn structure and for docking the 15.5K/NHPX snoRNP protein. Binding of $15.5 \mathrm{~K} / \mathrm{NHPX}$ induces a sharp band in the phosphodiester backbone of the two contiguous RNA stems of the Kink-turn (Vidovic et al. 2000; Szewczak et al. 2002, 2005; Watkins et al. 2002). This conformational change provides the structural requirements for the subsequent binding of Nop58, Nop56, and two copies of fibrillarin (Cahill et al. 2002). In vivo cross-linking experiments showed that one fibrillarin and Nop58 bind to the box D and C sequences in the upper stem of Kinkturn, respectively (Cahill et al. 2002). Nop56 and another copy of fibrillarin can be cross-linked to internal copies of the $\mathrm{C}$ and $\mathrm{D}$ boxes, termed the $\mathrm{C}^{\prime}$ and $\mathrm{D}^{\prime}$ boxes. Docking of these proteins is likely facilitated by protein-protein interactions, since generally the $\mathrm{C}^{\prime}$ and $\mathrm{D}^{\prime}$ boxes show poor sequence conservation (Kiss-László et al. 1998).

The Steitz group noticed that human box C/D snoRNAs possess a preferential intronic location. Namely, most box C/D snoRNAs are located about 80-90 nucleotides upstream of the $3^{\prime}$ splice site (Hirose and Steitz 2001). In vivo and in vitro snoRNA processing experiments confirmed that an optimal distance of about 50 nucleotides between the snoRNA coding region and the branch point of the host intron is required for efficient snoRNA processing. Increasing or decreasing the spacer length between the snoRNA and the branch point seriously compromises snoRNA accumulation (Hirose and Steitz 2001; Hirose et al. 2003). By using a coupled in vitro splicing/snoRNA processing system, the Steitz group demonstrated that recruitment of $15.5 \mathrm{~K} / \mathrm{NHPX}$ to box $\mathrm{C} / \mathrm{D}$ intronic snoRNAs occurs specifically at the $\mathrm{C} 1$ splicing complex stage, indicating that $15.5 \mathrm{~K} / \mathrm{NHPX}$ is actively recruited to intronic box $\mathrm{C} / \mathrm{D}$ snoRNAs by a splicingdependent mechanism (Fig. 1) (Hirose et al. 2003). They proposed that a putative box C/D snoRNP assembly factor (AF) that interacts directly or indirectly with the U2 spliceosomal snRNP, or another splicing factor associated with the branch point region in the $\mathrm{C} 1$ splicing com- plex, recruits and deposits the 15.5K/NHPX protein onto the Kink-turn of box C/D snoRNAs. Identification of putative factors promoting the splicing-dependent assembly of box C/D intronic snoRNPs requires further efforts.

\section{COUPLING BOX H/ACA SNORNP ASSEMBLY WITH POLYMERASE II TRANSCRIPTION}

In contrast to box C/D snoRNAs, human H/ACA snoRNAs have no preferential intronic location relative to the $5^{\prime}$ or $3^{\prime}$ splice sites of the host introns (Richard et al. 2006; Schattner et al. 2006). Moreover, whereas most box C/D snoRNA genes are found within relatively short introns, human box H/ACA snoRNAs tend to reside within introns of longer than average length. Consistent with this, human box H/ACA snoRNAs are processed from the introns of transiently expressed natural or artificial host pre-mRNAs in a position-independent fashion, indicating that the splicing machine does not participate in the assembly of intronic box H/ACA snoRNPs (Richard et al. 2006).

Chromatin and pre-mRNA coimmunoprecipitation and in situ localization experiments demonstrated that binding of dyskerin, Nhp2, and Nop10 snoRNP proteins to intronic H/ACA snoRNAs is an early event that occurs shortly after or already during the synthesis of the host premRNA (Fig. 2) (Darzacq et al. 2006; Richard et al. 2006). In vivo processing studies performed on transiently expressed artificial pre-mRNA transcripts confirmed that assembly of box H/ACA snoRNPs already occurs on the newly synthesized pre-mRNAs and demonstrated that snoRNP assembly and splice site selection, although they occur at the same time, are independent molecular events (Darzacq et al. 2006; Richard et al. 2006).

Correct and efficient expression of mammalian box H/ACA snoRNPs requires RNA polymerase (RNAP) II transcription (Richard et al. 2006). Precursor snoRNAs synthesized by RNAP III or RNAP I are either not processed or are poorly processed, and the resulting maturesized snoRNAs fail to correctly localize in the nucleolus. This suggests that an RNAP-II-associated factor may promote the cotranscriptional assembly of box H/ACA presnoRNPs. In fact, expression of both yeast and mammalian H/ACA snoRNPs requires two evolutionarily conserved H/ACA-specific processing/assembly factors, Naf1 and Shq1 (Dez et al. 2002; Fatica et al. 2002; Yang et al. 2002; Hoareau-Aveilla et al. 2006). Yeast Naf1 and Shq1 can form a complex, and they can interact with the box H/ACA snoRNP core proteins, dyskerin (Cbf5p in yeast) and Nhp2. Moreover, yeast Naf1 specifically associates with the carboxy-terminal domain (CTD) of the largest subunit of RNAP II (Fatica et al. 2002). Recombinant mammalian dyskerin, Nop10, and Nhp2 are capable of forming a protein-only complex that can specifically bind to H/ACA RNAs (Wang and Meier 2004; Darzacq et al. 2006). Naf1 may recruit the dyskerin/ Nop10/Nhp2 H/ACA protein core complex to the newly synthesized intronic H/ACA pre-snoRNAs through interacting with dyskerin and CTD (Fig. 2). Consistent with its involvement in coupling H/ACA snoRNP assembly with RNAP II transcription, Naf1 specifically associates with 
actively transcribed H/ACA snoRNA genes, both in yeast and mammalian cells (Ballarino et al. 2005; Yang et al. 2005; Darzacq et al. 2006). It remains uncertain when and where Gar1, the last-binding H/ACA protein, binds to the maturing snoRNP. Gar1 is essential for snoRNA-directed pseudouridylation, but it is dispensable for accumulation of box H/ACA snoRNAs (Bousquet-Antonelli et al. 1997). Under in vitro conditions, Naf1 and Gar1 bind competitively to dyskerin, suggesting that Gar1 may replace Naf1 at a later stage of H/ACA snoRNP biogenesis (Darzacq et al. 2006).

\section{MULTIPLE TRANS-ACTING FACTORS ARE INVOLVED IN MAMMALIAN SNORNP BIOGENESIS}

Besides the box C/D and H/ACA snoRNP core proteins, several trans-acting protein factors have been implicated in the biogenesis of snoRNPs. Although most of the available data were obtained in the yeast Saccharomyces cerevisiae system, recent studies on human U3 snoRNP assembly gave new insights into the biogenesis of human box C/D snoRNPs (Verheggen et al. 2001, 2002; Boulon et al. 2004; Watkins et al. 2004). U3 is the most abundant mammalian snoRNA that is transcribed from independent genes by RNAP II, instead of being processed from pre-mRNA introns. During the nucleoplasmic biosynthesis of U3 snoRNP, the precursor U3 snoRNA that carries a short uridine-rich 3' trailer transiently interacts with numerous non-snoRNP proteins to form a large, structurally dynamic, multiprotein processing complex that is, in fact, larger than the mature U3 snoRNP accumulating in the nucleolus (Boulon et al. 2004; Watkins et al. 2004). The proteins which transiently associate with precursor U3 include known RNA processing factors (TGS1, La, LSm4, and Rrp46), putative RNP assembly factors (Nopp140, Tip48, and Tip49), and well-characterized RNA export factors (CRM1, PHAX, Ran, and the cap binding complex [CBC]).

The La, LSm4, and Rrp46 proteins associate exclusively with the $3^{\prime}$-extended precursor of U3, indicating that these proteins function in the $3^{\prime}$ end formation of the U3 snoRNA (Watkins et al. 2004). Indeed, the La and Lsm4 proteins, the latter as a component of the Lsm 2 to Lsm8 heteroheptameric complex, possess well-established functions in stabilizing and processing of mature $3^{\prime}$ ends of tRNAs, snRNAs, and snoRNAs (Achsel et al. 1999; Perumal and Reddy 2002; Wolin and Cedervall 2002; Beggs 2005; Maraia and Bayfield 2006). The La and Lsm proteins likely provide stability for the nascent U3 snoRNA through binding to its uridine-rich 3' overhang. Rpr46 is an integral component of the human nuclear exosome complex which consists of multiple $3^{\prime}$ to $5^{\prime}$ exoribonucleases. Therefore, Rpr46 likely participates in the $3^{\prime}$ end trimming of U3 (Allmang et al. 1999; Vasiljeva and Buratowski 2006). The Lsm heteroheptameric complex associated with the $3^{\prime}$ terminal trailer of the precursor U3 snoRNA may recruit the exosome complex to the maturing U3 snoRNP (Fromont-Racine et al. 2000). Like all RNAP II transcripts, the nascent U3 snoRNA contains a monomethyl-G $(\mathrm{m} 7 \mathrm{G})$ cap structure that is hypermethylated to mature trimethyl-G (TMG) by the TGS1 methyltransferase (Mouaikel et al. 2002).

An important question is whether the information obtained on the processing of the RNAP II-transcribed U3 snoRNA holds true for the biogenesis of intron-encoded box C/D snoRNAs. RNAi-mediated depletion experiments demonstrated that all factors implicated in U3 maturation, apart from the easily understandable exception of the TGS1 methyltransferase, are also important for the accumulation of the intron-encoded U14 snoRNA (Watkins et al. 2004). This indicates that the nuclear machines supporting the biogenesis of independently transcribed and intron-encoded box C/D snoRNPs share common structural and functional principles.

Moreover, it seems that some essential components of the mammalian "box C/D processome," namely the Nopp140, Tip48, and Tip49 proteins, also function in the biogenesis of box H/ACA snoRNPs. Nopp140 is a phosphoprotein that was found to associate with both box H/ACA and C/D snoRNPs (Meier and Blobel 1994; Isaac et al. 1998; Yang et al. 2000; Wang et al. 2002). Depletion of Nopp140 inhibits the accumulation of both box C/D and H/ACA snoRNAs (Isaac et al. 1998; Yang et al. 2000; Watkins et al. 2004). Two other "U3 processome"-associated proteins, Tip48 and Tip49 (also called p50 and p55), were first identified by using a mouse in vitro box C/D snoRNP reconstitution system (Newman et al. 2000). Tip48/p50 and Tip49/p55 are evolutionarily conserved interrelated proteins with ATPase and DNA helicase activity (Ikura et al. 2000). Since Tip48/p50 and Tip49/p55 reside in the nucleoplasm and do not associate with mature nucleolar snoRNPs, they were proposed to function in the assembly and/or nucleolar transport of box $\mathrm{C} / \mathrm{D}$ snoRNPs. Indeed, genetic depletion of the yeast equivalents of Tip48 and Tip49 (Rvb1p and Rvb2p) diminished accumulation of box C/D snoRNPs and, unexpectedly, also blocked box H/ACA snoRNP production, demonstrating that Tip48/Rvb1p and Tip49/Rvb2p, together with Nopp140, function as general snoRNP biogenesis factors (King et al. 2001). Nopp140 and Tip49 associate with mature-sized TMG-capped U3 snoRNA in the nucleoplasm, suggesting that they function in the last steps of the nucleoplasmic biogenesis of snoRNPs (Watkins et al. 2004).

The survival of motor neurons protein (SMN), the protein product of a gene responsible for spinal muscular atrophy (SMA), is an essential component of a macromolecular complex required for the assembly of snRNPs (for review, see Paushkin et al. 2002; Yong et al. 2004). SMN has been reported to specifically interact in vivo and in vitro with fibrillarin and Gar1, leading to the notion that SMN is involved in the assembly of both box C/D and H/ACA snoRNPs (Jones et al. 2001; Pellizzoni et al. 2001; Terns and Terns 2001). Expression of a dominantnegative mutant of SMN caused fibrillarin, Gar1, and U3 snoRNP to accumulate outside the nucleolus (Pellizzoni et al. 2001). Depletion of HeLa SMN protein resulted in reduced levels of U3 snoRNA, further supporting an SMN function in U3 snoRNP biogenesis (Watkins et al. 2004). However, in the above experiment, loss of SMN had no significant effect on the accumulation of the U8 
and U14 box C/D snoRNAs. Therefore, further studies are required to clarify the function of SMN in mammalian snoRNP biogenesis.

\section{INTRANUCLEAR TRAFFICKING OF MATURING BOX C/D AND H/ACA SNORNPs}

Whereas binding of the $15.5 \mathrm{~K} / \mathrm{NHPX}$ box $\mathrm{C} / \mathrm{D}$ and the dyskerin, Nhp2, and Nop10 box H/ACA snoRNP core proteins to nascent intronic snoRNAs occurs in the nucleoplasm at the site of host pre-mRNA transcription and splicing, it remains largely speculative where subsequent steps of mammalian snoRNP maturation take place. Precursor snoRNAs are not detectable in the nucleolus, indicating that only fully processed snoRNAs are transported into the nucleolus (Samarsky et al. 1998; Verheggen et al. 2002). Binding of snoRNP proteins is essential not only for snoRNA processing and stability, but also for targeting mature snoRNPs into the nucleolus. Therefore, the snoRNA core structures, namely the box $\mathrm{C} / \mathrm{D}$ and H/ACA elements and the neighboring helix structures, that direct snoRNP protein binding, also function as nucleolar localization signals (Lange et al. 1998, 1999; Samarsky et al. 1998; Narayanan et al. 1999a,b; Verheggen et al. 2001). A more recent study found that box C/D snoRNP proteins lack a simple, structurally welldefined nucleolar targeting motif. Instead, the four box C/D snoRNP proteins collectively constitute an efficient nucleolar localization signal (Verheggen et al. 2001).

Early snoRNA trafficking studies found that fluorescein-labeled box C/D snoRNAs injected into Xenopus oocyte nuclei transiently appear in the nucleoplasmic Cajal bodies before accumulating in the nucleolus (Narayanan et al. 1999a). In mammalian cells, both endogenous and ectopically expressed box C/D snoRNAs show a weak Cajal-body-specific accumulation beside massive concentration in the nucleolus (Samarsky et al. 1998; Darzacq et al. 2002). In contrast to box C/D snoRNAs, box H/ACA snoRNAs microinjected into Xenopus oocytes show no Cajal-body-specific accumulation, and endogenous mammalian box H/ACA snoRNAs are not detectable in the Cajal body (Narayanan et al. 1999b). However, plant box H/ACA snoRNAs and, upon overexpression, mammalian box H/ACA snoRNAs, appear in Cajal bodies (Shaw et al. 1998; Richard et al. 2003). It is therefore possible that both box $\mathrm{C} / \mathrm{D}$ and H/ACA snoRNPs accumulate in Cajal bodies prior to nucleoli, but box H/ACA snoRNAs traverse the Cajal body more rapidly than box C/D snoRNAs do. Transient accumulation of box $\mathrm{C} / \mathrm{D}$ and perhaps box $\mathrm{H} / \mathrm{ACA}$ snoRNPs in Cajal bodies strongly suggests that some steps of snoRNP biogenesis occur in this nuclear organelle. Consistent with a function in snoRNP biogenesis, the Cajal body had long been known to contain the fibrillarin, dyskerin, and Garl snoRNP proteins, and the putative snoRNP assembly/processing factor, Nopp140 (Meier and Blobel 1994; Bohmann et al. 1995; Narayanan et al. 1999b).

A more recent study on the biogenesis of U3 snoRNP provided further evidence for the participation of Cajal body in snoRNP maturation (Verheggen et al. 2002). The 3'-extended precursor of human U3 snoRNA that carries a monomethyl-G primary cap accumulates both at the site of transcription and within the Cajal body, but it is excluded from the nucleolus. The precursor U3 snoRNA is localized to the transcription site and the Cajal body is associated with $15.5 \mathrm{~K} / \mathrm{NHPX}$, but it is still not assembled with fibrillarin and Nop58. Importantly, the mature-sized U3 snoRNA that carries a TMG cap and associates with all $\mathrm{C} / \mathrm{D}$ snoRNP proteins is also detectable in the Cajal body, although it accumulates mainly in the nucleolus. These observations indicate that association of the latebinding box C/D snoRNP proteins, final 3' end trimming, and cap hypermethylation of the U3 snoRNA take place in the Cajal body. Consistently, the nuclear fraction of the human methyltransferase TGS1 responsible for U3 cap hypermethylation accumulates in the Cajal body.

Contrary to the fact that snoRNP maturation has no cytoplasmic phase (Terns and Dahlberg 1994; Terns et al. 1995), processing of U3 snoRNA depends on transport factors with well-established roles in the nucleocytoplasmic snRNA transport (Boulon et al. 2004; Watkins et al. 2004). Like RNAP-II-specific nascent spliceosomal snRNAs, the newly synthesized U3 precursor associates with the m7G-cap-binding complex (CBP) and PHAX (phosporylated adapter for RNA export) (Fig. 3). However, in the case of U3, binding of PHAX is not followed by recruitment of the transport factors CRM1 and Ran-GTP, which is required for the cytoplasmic transportation of nascent snRNAs (Ohno et al. 2002). In vivo depletion experiments confirmed that $\mathrm{U} 3$ is targeted into the Cajal body by a PHAX-dependent and CRM1-independent mechanism. Efficient targeting of U3 into the Cajal body, in addition to the $\mathrm{m} 7 \mathrm{G}$ cap, also requires an intact terminal box $\mathrm{C}^{\prime} / \mathrm{D}$ motif (the Kink-turn) (Boulon et al. 2004). Since these two cis-acting Cajal body localization elements of U3 function synergistically, it is possible that besides $\mathrm{CBC}$, additional not yet identified factors contribute to the recruitment of PHAX to the nascent U3 snoRNA, or alternatively, PHAX directly interacts with 15.5/NHPX bound to the box C'/D motif of U3 (Boulon et al. 2004). Coimmunoprecipitation experiments found PHAX to be associated with other RNAP-II-transcribed box C/D snoRNAs, U8 and U13, as well as with the human telomerase RNA that carries a box H/ACA snoRNA-like domain (see below). Moreover, depletion of PHAX inhibited the accumulation of the intron-encoded U14 box C/D snoRNA (Watkins et al. 2004). Hence, it is possible that PHAX functions in the intranuclear trafficking of both box C/D and box H/ACA snoRNPs.

In the Cajal body, the precursor U3 snoRNA is packaged with box C/D core proteins and undergoes $3^{\prime}$ end processing and TMG cap formation before translocation into the nucleolus (Fig. 3) (Verheggen et al. 2002). Surprisingly, depletion experiments found that targeting of mature U3 snoRNP from the Cajal body into the nucleolus requires CRM1 (Boulon et al. 2004; Watkins et al. 2004). Indeed, coimmunoprecipitation experiments confirmed that CRM1 interacts with $\mathrm{U} 3$ and associates mainly, if not exclusively, with mature-sized, TMGcapped U3 snoRNAs, supporting the idea that CRM1 functions in a late step of U3 snoRNP biogenesis. 


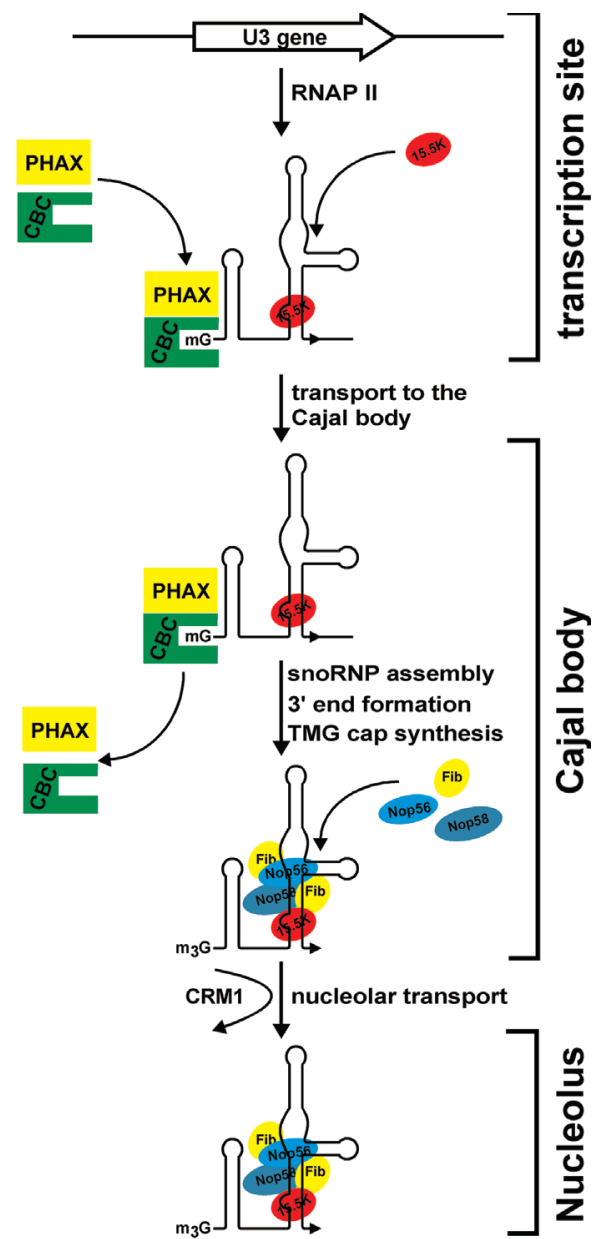

Figure 3. Model for assembly and intranuclear trafficking of mammalian U3 snoRNP. The box $C^{\prime} / D$ motif (Kink turn) of the 3 -extended nascent U3 snoRNA binds the $15.5 \mathrm{~K} / \mathrm{NHPX}$ protein. Binding of $\mathrm{CBC}$ and PHAX to the $\mathrm{m} 7 \mathrm{G}$ monomethyl cap $(\mathrm{mG})$ supports U3 transport into the Cajal body where maturation of U3 snoRNA and assembly of U3 snoRNP is completed. A transient interaction with CRM1 is essential for routing mature U3 snoRNP into the nucleolus. It seems that the mammalian intron-encoded snoRNPs follow a processing/trafficking pathway similar or identical to that described for the U3 snoRNP.

\section{SMALL CAJAL-BODY-SPECIFIC RNPS}

The Cajal body is an evolutionarily conserved, multifunctional subnuclear organelle (Ogg and Lamond 2002; Gall 2003; Cioce and Lamond 2005). The RNAP-II-specific U1, U2, U4, and U5 Sm spliceosomal snRNPs had long been known to cycle through Cajal bodies and were suspected to undergo maturation in this nuclear organelle (Carmo-Fonseca et al. 1992; Bohmann et al. 1995; Sleeman and Lamond 1999). The mature snRNAs carry numerous posttranscriptionally synthesized 2'-Omethylated nucleotides and pseudouridines (Massenet et al. 1998). During the past years, several box C/D 2'-Omethylation and box H/ACA pseudouridylation guide RNAs have been identified and demonstrated, or confidently predicted, to function in the modification of human Sm snRNAs (Lestrade and Weber 2006 and ref- erences therein). The first guide RNA linked to Sm snRNA modification, U85, showed an unusual structural organization, because it contained both a box C/D and a box H/ACA snoRNA-like domain (Fig. 4) (Jády and Kiss 2001). The H/ACA domain of U85 is inserted into the middle of its box $\mathrm{C} / \mathrm{D}$ domain. In vivo and in vitro modification experiments demonstrated that the box C/D domain of U85 directs 2'-O-methylation, whereas its box H/ACA domain guides pseudouridylation of the U5 snRNA. Later, additional box C/D-H/ACA composite guide RNAs directing $\mathrm{Sm}$ snRNA modification were discovered, and another guide RNA, U93, which directs pseudouridylation of the U2 snRNA, was found to contain two tandemly arranged H/ACA RNA domains (Darzacq et al. 2002; Kiss et al. 2002). Moreover, irregular structural arrangements were also observed for box C/D RNAs directing 2'-O-methylation of Sm snRNAs. These guide RNAs are significantly longer than canonical box C/D snoRNAs involved in rRNA methylation and they are frequently composed of two box C/D-like domains and carry a $\mathrm{m} 7 \mathrm{G}$ cap, indicating that they are RNAP II transcripts (Darzacq et al. 2002; Tycowski et al. 2004).

Cell fractionation and in situ localization experiments revealed that all modification guide RNAs implicated in $2^{\prime}$ O-methylation and/or pseudouridylation of Sm snRNAs specifically accumulate in Cajal bodies and were therefore called small Cajal-body-specific RNAs (scaRNAs) (Darzacq et al. 2002; Kiss et al. 2002, 2004). Accumulation
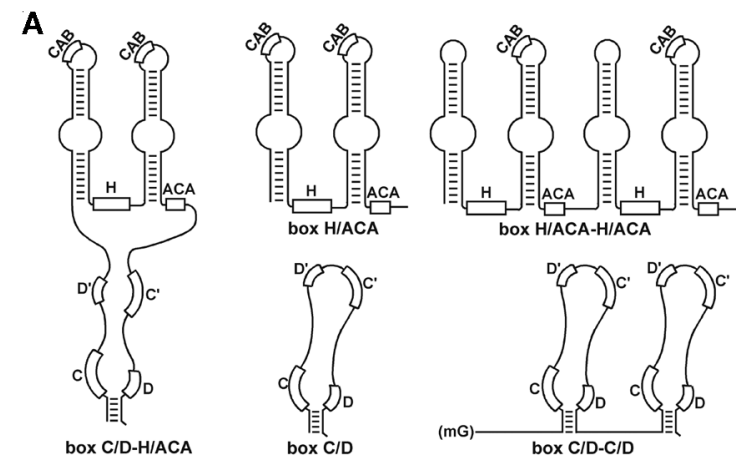

box C/D-H/ACA

box $C / D$

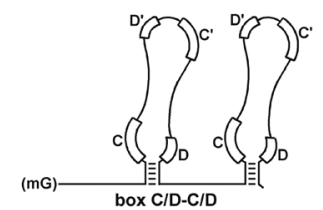

B

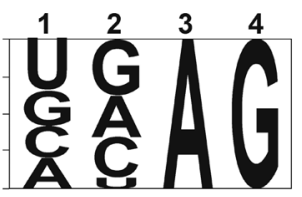

Figure 4. Human small Cajal-body-specific RNAs (scaRNAs). (A) Schematic structural organization of human scaRNAs. Positions of the conserved box elements are indicated. Box H/ACA scaRNAs possess a Cajal-body-specific localization element ( $\mathrm{CAB}$ box) that is located in the terminal loop of the $5^{\prime}$ or 3' hairpin. Some H/ACA scaRNAs have two CAB boxes. Elements supporting the Cajal-body-specific accumulation of box C/D scaRNAs are unknown. $(B)$ Sequence conservation of the CAB box motifs of vertebrate scaRNAs. The frequencies of the four ribonucleotides $\mathrm{G}, \mathrm{A}, \mathrm{U}$, and $\mathrm{C}$ in the four positions of 278 putative $\mathrm{CAB}$ box motifs identified in vertebrate scaRNAs are indicated by the heights of the corresponding letters. 
of scaRNAs in the Cajal body instead of the nucleolus was unexpected, since they carry the box H/ACA and/or C/D motifs responsible for the nucleolar localization of snoRNAs (see above). A sequence comparison followed by mutational analysis demonstrated that the terminal loop of the $5^{\prime}$ or the $3^{\prime}$ hairpin of H/ACA scaRNAs contains a short Cajal-body-specific localization motif, the Cajal body box (CAB box) (Richard et al. 2003). In a few cases, both the $5^{\prime}$ and $3^{\prime}$ hairpins carry a CAB box motif that seems to function synergistically. Upon alteration of the CAB box motifs, the mutant H/ACA scaRNAs accumulate in the nucleolus, and authentic box H/ACA snoRNAs can be targeted into the Cajal body by inclusion of an exogenous $\mathrm{CAB}$ box. The original CAB box consensus (ugAG) was based on a handful of human scaRNA sequences (Richard et al. 2003). More recently, experimental and computerbased approaches identified numerous putative box H/ACA scaRNAs from a broad variety of vertebrate organisms (Lestrade and Weber 2006 and references therein). The frequency of ribonucleotides observed at each position of 278 putative CAB box motifs is shown in Figure 4B. Mutational analysis confirmed that the first two nucleotides are less critical, whereas the highly conserved final two nucleotides (AG) are absolutely essential for the Cajalbody-specific accumulation of scaRNAs. So far, no Cajalbody-specific localization element has been identified in box C/D scaRNAs that lack an H/ACA domain.

Since both box C/D and H/ACA snoRNAs may transit through Cajal bodies, it is possible that the Cajal body localization signal of scaRNAs is a retention element that prevents translocation of scaRNPs from the Cajal body to the nucleolus. Most probably, the CAB box functions through binding a specific protein factor(s) (Richard et al. 2003). Fu and Collins have recently proposed that two Sm proteins, $\mathrm{SmB}$ and $\mathrm{SmD} 3$, associate directly or indirectly with the $\mathrm{CAB}$ box of a subpopulation of human box H/ACA scaRNAs and the telomerase RNA that is in fact an H/ACA scaRNA (see below) (Fu and Collins 2006). However, telomerase RNA microinjected into Xenopus oocytes did not associate with Sm proteins and, in human HeLa cells, we failed to detect an interaction between Sm proteins and box H/ACA scaRNAs, including the human telomerase RNA (Lukowiak et al. 2001; our unpublished data). This may indicate that interaction of $\mathrm{SmB}$ and SmD3 proteins with scaRNAs may depend on growth conditions and/or cell lines.

\section{HUMAN TELOMERASE IS A BOX H/ACA SCARNP}

Telomerase is a ribonucleoprotein enzyme that is responsible for the synthesis of telomeric DNA at the ends of eukaryotic linear chromosomes (Collins and Mitchell 2002; Cong et al. 2002). The telomerase holoenzyme is composed of the telomerase RNA (TR) and a set of associated proteins, including the telomerase reverse transcriptase (TERT). TR provides a scaffold for binding of telomerase RNP proteins and contains the template region that is copied repeatedly by the associated TERT to produce telomeric DNA repeats (Fig. 5A). The human TR (hTR) is divided into two major structural domains (Fig.
5B). The $5^{\prime}$ half of hTR that carries the template sequence folds into a large pseudoknot structure that is an evolutionarily conserved feature of TRs. The 3' terminal region of hTR possesses a box H/ACA RNA-like structure and is associated with the four box H/ACA snoRNP core proteins, dyskerin, Nhp2, Nop10, and Gar1 (Mitchell et al. 1999; Chen et al. 2000; Antal et al. 2002; Meier 2005). The H/ACA domain provides metabolic stability for human telomerase RNP and is also indispensable for the enzymatic activity of telomerase (Mitchell et al. 1999; Mitchell and Collins 2000; Martin-Rivera and Blasco 2001; Chen et al. 2002; Fu and Collins 2003).

In situ localization experiments showed that in human cancer cells, both endogenous and ectopically expressed hTRs accumulate in Cajal bodies (Jády et al. 2004; Zhu et al. 2004). Mutational analysis revealed that targeting of hTR into Cajal bodies is supported by a short signal sequence, UGAG, which is located in the terminal loop of the $3^{\prime}$ hairpin of the H/ACA domain of hTR, and is structurally and functionally indistinguishable from the $\mathrm{CAB}$ box motif of box H/ACA scaRNAs (Fig. 5B) (Jády et al. 2004). The $3^{\prime}$ terminal box H/ACA domain of hTR contains all the elements required for the correct expression of canonical intron-encoded box H/ACA scaRNAs, because it is efficiently processed from the second intron of the human $\beta$-globin pre-mRNA expressed in human or mouse cells and the excised RNA accumulates in Cajal bodies (our unpublished data).

However, although authentic scaRNAs are normally not detectable outside the Cajal body, hTR accumulation is not confined to this nuclear organelle. Instead, hTR has a complex and dynamic intranuclear trafficking that seems to be strictly regulated by the cell cycle. In the nuclei of HeLa Sphase cells, besides accumulating in Cajal bodies, hTR
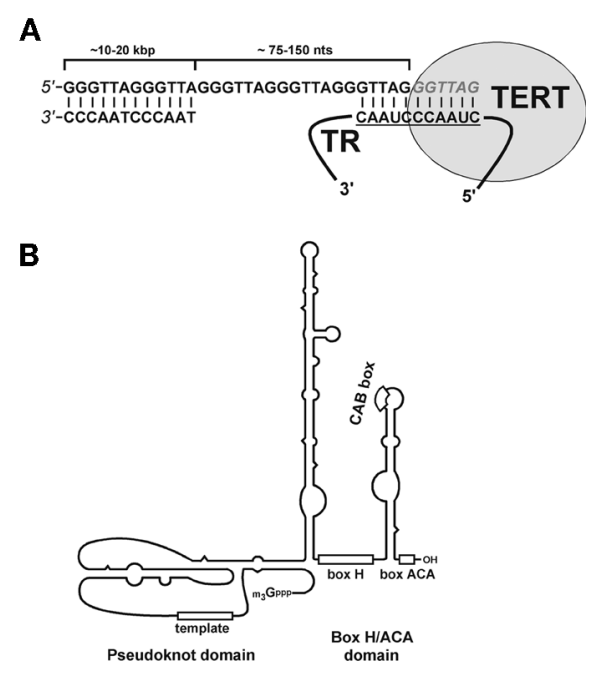

Figure 5. Structure and function of human telomerase RNA. (A) Synthesis of telomeric DNA by telomerase. The template sequence (underlined) of telomerase RNA (TR) recognizes the terminal nucleotides of the telomeric $\mathrm{G}$ strand. The telomerase reverse transcriptase (TERT) incorporates deoxynucleotides (in italics) complementary to the template sequence of TR. (B) Schematic structure of human telomerase RNA. Positions of the template region, the $\mathrm{H}, \mathrm{ACA}$, and $\mathrm{CAB}$ boxes are shown. 
also concentrates at a few (most frequently 1 to 3 ) telomeres (Jády et al. 2006; Tomlinson et al. 2006). Accumulation of hTR at telomeres likely reflects telomere elongation events. This is supported by the facts that telomere synthesis is known to occur during S-phase and that hTERT also concentrates at a few telomeres in HeLa S-phase cells (Ten Hagen et al. 1990; Wright et al. 1999; Tomlinson et al. 2006). Telomeres accumulating hTR feature long $\mathrm{G}$ strands that, in marked contrast to the majority of telomeres, are accessible for in situ hybridization with a G-strand-specific fluorescent oligonucleotide probe without denaturation (Jády et al. 2006). The highly accessible $\mathrm{G}$ strands may represent nascent telomeric overhangs synthesized by the associated telomerase. The notion that human telomerase accumulates only at a few telomeres implies that only a small subset of human telomeres are elongated within one cell cycle, as has been demonstrated in yeast, where telomerase extends less than $10 \%$ of telomeres during every cell cycle (Teixeira et al. 2004). Therefore, intranuclear trafficking of hTR may play an important regulatory role in human telomere synthesis (Jády et al. 2006; Tomlinson et al. 2006).

The cis- and trans-acting elements supporting hTR accumulation at telomeres remain unknown. The $3^{\prime}$ terminal H/ACA domain of hTR alone, when expressed in HeLa cells, fails to concentrate at telomeres, suggesting that the $5^{\prime}$ terminal template domain is required for targeting hTR to telomeres (our unpublished data). Interestingly, more than $25 \%$ of HeLa telomeres accumulating hTR colocalize with Cajal bodies, suggesting that Cajal bodies may function in some aspects of human telomere biogenesis (Jády et al. 2006). The Cajal body is a mobile subnuclear organelle that can translocate large distances through the nucleoplasm and therefore has been implicated in the intranuclear transport and sorting of nuclear factors (Platani et al. 2000, 2002; Ogg and Lamond 2002; Cioce and Lamond 2005). In vivo imaging demonstrated that in HeLa S-phase cells, Cajal bodies moving in the interchromatin space transiently associate with telomeres with a frequency of approximately 1.8 associations per hour. This indicates that during the entire $\mathrm{S}$ phase, Cajal bodies interact with 5-7 telomeres (Jády et al. 2006). The biological significance of the cell-cycleregulated interaction of Cajal bodies with telomeres remains unclear, but according to an attractive hypothesis, Cajal bodies may deliver hTR to telomeres.

\section{CONCLUSIONS}

Studies during the past years revealed that biogenesis of mammalian box C/D and H/ACA snoRNPs is a more complex process than previously anticipated. Assembly of functional box $\mathrm{C} / \mathrm{D}$ and $\mathrm{H} / \mathrm{ACA}$ snoRNPs requires numerous auxiliary factors, in addition to the four box C/D and H/ACA snoRNP proteins. The initial steps of the assembly of intronic snoRNPs, namely recognition of the nascent box H/ACA and C/D snoRNA sequences through recruitment of the first-binding snoRNP proteins, are actively facilitated by the RNAP II transcription complex or the pre-mRNA splicing machinery. Maturing of box C/D and
H/ACA snoRNPs requires an intranuclear trafficking of the maturing snoRNPs from the site of snoRNA synthesis to the site of the function of the mature snoRNP. Different steps of box C/D and H/ACA RNP maturation can be linked to subnuclear compartments where the maturing snoRNPs transit through. The mature box $\mathrm{C} / \mathrm{D}$ and H/ACA snoRNPs involved in rRNA modification or maturation accumulate in the nucleolus, whereas box C/D and H/ACA RNPs directing spliceosomal snRNA modification reside in the Cajal body (scaRNPs). Sequestering the functionally active guide RNPs into the nucleolus or Cajal body may be an important mechanism to avoid undesired RNA modification events in the nucleoplasm. The human telomerase RNA (hTR) accumulates in Cajal bodies and shares a common Cajal body localization element with box H/ACA scaRNAs. However, hTR shows a more complex intranuclear localization pattern. In S-phase cells, hTR specifically accumulates at a few telomeres that possess long G-strand overhangs. Hence, studies on the biosynthesis of mammalian snoRNPs and scaRNPs revealed unexpected principles of the intranuclear trafficking of macromolecules and gave new insights into the molecular mechanism of the assembly of small RNPs.

\section{ACKNOWLEDGMENTS}

This work was supported by grants from la Ligue Nationale contre le Cancer and la Fondation pour la Recherche Médicale. E.F. and P.R. were supported by le Ministère l'Education Nationale, de la Recherche, et de la Technologie and la Fondation pour la Recherche Médicale, respectively.

\section{REFERENCES}

Achsel T., Brahms H., Kastner B., Bachi A., Wilm M., and Lührmann R. 1999. A doughnut-shaped heteromer of human Sm-like proteins binds to the $3^{\prime}$-end of U6 snRNA, thereby facilitating $\mathrm{U} 4 / \mathrm{U} 6$ duplex formation in vitro. EMBO J. 18: 5789.

Allmang C., Kufel J., Chanfreau G., Mitchell P., Petfalski E., and Tollervey D. 1999. Functions of the exosome in rRNA, snoRNA and snRNA synthesis. EMBO J. 18: 5399.

Antal M., Boros E., Solymosy F., and Kiss T. 2002. Analysis of the structure of human telomerase RNA in vivo. Nucleic Acids Res. 30: 912

Bachellerie J.P., Cavaillé J., and Hüttenhofer A. 2002. The expanding snoRNA world. Biochimie 84: 775.

Balakin A.G., Smith L., and Fournier M.J. 1996. The RNA world of the nucleolus: Two major families of small RNAs defined by different box elements with related functions. Cell 86: 823 .

Ballarino M., Morlando M., Pagano F., Fatica A., and Bozzoni I. 2005. The cotranscriptional assembly of snoRNPs controls the biosynthesis of H/ACA snoRNAs in Saccharomyces cerevisiae. Mol. Cell. Biol. 25: 5396.

Beggs J.D. 2005. Lsm proteins and RNA processing. Biochem. Soc. Trans. 33: 433.

Bertrand E. and Fournier M.J. 2004. The snoRNPs and related machines: Ancient devices that mediate maturation of rRNA and other RNAs. In The nucleolus (ed. M.O.J. Olson), p. 225. Kluwer Academic/Plenum Publishers, New York and Landes Bioscience, Georgetown, Texas.

Bohmann K., Ferreira J., Santama N., Weis K., and Lamond A.I. 1995. Molecular analysis of the coiled body. J. Cell Sci. (suppl.) 19: 107. 
Boulon S., Verheggen C., Jády B.E., Girard C., Pescia C., Paul C., Ospina J.K., Kiss T., Matera A.G., Bordonne R., and Bertrand E. 2004. PHAX and CRM1 are required sequentially to transport U3 snoRNA to nucleoli. Mol. Cell 16: 777.

Bousquet-Antonelli C., Henry Y., G'Elugne J P., CaizerguesFerrer M., and Kiss T. 1997. A small nucleolar RNP protein is required for pseudouridylation of eukaryotic ribosomal RNAs. EMBO J. 16: 4770 .

Cahill N.M., Friend K., Speckmann W., Li Z.H., Terns R.M., Terns M.P., and Steitz J.A. 2002. Site-specific cross-linking analyses reveal an asymmetric protein distribution for a box C/D snoRNP. EMBOJ. 21: 3816.

Carmo-Fonseca M., Pepperkok R., Carvalho M.T., and Lamond A.I. 1992. Transcription-dependent colocalization of the U1, U2, U4/U6, and U5 snRNPs in coiled bodies. J. Cell Biol. 117: 1 .

Cavaillé J. and Bachellerie J.P. 1996. Processing of fibrillarinassociated snoRNAs from pre-mRNA introns: An exonucleolytic process exclusively directed by the common stem-box terminal structure. Biochimie 78: 443.

Cavaillé J., Nicoloso M., and Bachellerie J.P. 1996. Targeted ribose methylation of RNA in vivo directed by tailored antisense RNA guides. Nature 383: 732.

Chen J.L., Blasco M.A., and Greider C.W. 2000. Secondary structure of vertebrate telomerase RNA. Cell 100: 503.

Chen J.L., Opperman K.K., and Greider C.W. 2002. A critical stem-loop structure in the CR4-CR5 domain of mammalian telomerase RNA. Nucleic Acids Res. 30: 592.

Cioce M. and Lamond A.I. 2005. Cajal bodies: A long history of discovery. Annu. Rev. Cell Dev. Biol. 21: 105

Collins K. and Mitchell J.R. 2002. Telomerase in the human organism. Oncogene 21: 564.

Cong Y.S., Wright W.E., and Shay J.W. 2002. Human telomerase and its regulation. Microbiol. Mol. Biol. Rev. 66: 407.

Darzacq X., Jády B.E., Verheggen C., Kiss A.M., Bertrand E., and Kiss T. 2002. Cajal body-specific small nuclear RNAs: A novel class of 2'-O-methylation and pseudouridylation guide RNAs. EMBO J. 21: 2746.

Darzacq X., Kittur N., Roy S., Shav-Tal Y., Singer R.H., and Meier U.T. 2006. Stepwise RNP assembly at the site of H/ACA RNA transcription in human cells. J. Cell Biol. 173: 207.

Decatur W.A. and Fournier M.J. 2003. RNA-guided nucleotide modification of ribosomal and other RNAs. J. Biol. Chem. 278: 695 .

Dennis P.P. and Omer A. 2005. Small non-coding RNAs in Archaea. Curr. Opin. Microbiol. 8: 685.

Dez C., Noaillac-Depeyre J., Caizergues-Ferrer M., and Henry Y. 2002. Naf1p, an essential nucleoplasmic factor specifically required for accumulation of box H/ACA small nucleolar RNPs. Mol. Cell. Biol. 22: 7053.

Fatica A., Dlakic M., and Tollervey D. 2002. Naf1 p is a box H/ACA snoRNP assembly factor. RNA 8: 1502 .

Filipowicz W. and Pogacic V. 2002. Biogenesis of small nucleolar ribonucleoproteins. Curr. Opin. Cell Biol. 14: 319.

Fragapane P., Prislei S., Michienzi A., Caffarelli E., and Bozzoni I. 1993. A novel small nucleolar RNA (U16) is encoded inside a ribosomal protein intron and originates by processing of the pre-mRNA. EMBO J. 12: 2921

Fromont-Racine M., Mayes A.E., Brunet-Simon A., Rain J.C., Colley A., Dix I., Decourty L., Joly N., Ricard F., Beggs J.D., and Legrain P. 2000. Genome-wide protein interaction screens reveal functional networks involving Sm-like proteins. Yeast 17: 95.

Fu D. and Collins K. 2003. Distinct biogenesis pathways for human telomerase RNA and H/ACA small nucleolar RNAs. Mol. Cell 11: 1361.

2006. Human telomerase and Cajal body ribonucleoproteins share a unique specificity of $\mathrm{Sm}$ protein association. Genes Dev. 20: 531.

Gall J.G. 2003. The centennial of the Cajal body. Nat. Rev. Mol. Cell Biol. 4: 975.

Ganot P., Bortolin M.L., and Kiss T. 1997a. Site-specific pseudouridine formation in preribosomal RNA is guided by small nucleolar RNAs. Cell 89: 799.
Ganot P., Caizergues-Ferrer M., and Kiss T. 1997b. The family of box ACA small nucleolar RNAs is defined by an evolutionarily conserved secondary structure and ubiquitous sequence elements essential for RNA accumulation. Genes Dev. 11: 941.

Green M.R. 1991. Biochemical mechanisms of constitutive and regulated pre-mRNA splicing. Annu. Rev. Cell Biol. 7: 559.

Henras A.K., Dez C., and Henry Y. 2004. RNA structure and function in C/D and H/ACA s(no)RNPs. Curr. Opin. Struct. Biol. 14: 335 .

Henras A., Henry Y., Bousquet-Antonelli C., Noaillac-Depeyre J., Gelugne J.P., and Caizergues-Ferrer M. 1998. Nhp2p and Nop10p are essential for the function of H/ACA snoRNPs. EMBO J. 17: 7078.

Hirose T. and Steitz J.A. 2001. Position within the host intron is critical for efficient processing of box C/D snoRNAs in mammalian cells. Proc. Natl. Acad. Sci. 98: 12914.

Hirose T., Shu M.D., and Steitz J.A. 2003. Splicing-dependent and -independent modes of assembly for intron-encoded box C/D snoRNPs in mammalian cells. Mol. Cell 12: 113.

Hoang C. and Ferre-D'Amare A.R. 2001. Cocrystal structure of a tRNA Psi55 pseudouridine synthase: Nucleotide flipping by an RNA-modifying enzyme. Cell 107: 929.

Hoareau-Aveilla C., Bonoli M., Caizergues-Ferrer M., and Henry Y. 2006. hNaf1 is required for accumulation of human H/ACA snoRNPs, scaRNPs and telomerase. RNA 12: 832.

Hüttenhofer A., Schattner P., and Polacek N. 2005. Non-coding RNAs: Hope or hype? Trends Genet. 21: 289.

Ikura T., Ogryzko V.V., Grigoriev M., Groisman R., Wang J., Horikoshi M., Scully R., Qin J., and Nakatani Y. 2000. Involvement of the TIP60 histone acetylase complex in DNA repair and apoptosis. Cell 102: 463.

Isaac C., Yang Y., and Meier U.T. 1998. Nopp140 functions as a molecular link between the nucleolus and the coiled bodies. J. Cell Biol. 142: 319.

Jády B.E. and Kiss T. 2001. A small nucleolar guide RNA functions both in 2'-O-ribose methylation and pseudouridylation of the U5 spliceosomal RNA. EMBO J. 20: 541.

Jády B.E., Bertrand E., and Kiss T. 2004. Human telomerase RNA and box H/ACA scaRNAs share a common Cajal bodyspecific localization signal. J. Cell Biol. 164: 647.

Jády B.E., Richard P., Bertrand E., and Kiss T. 2006. Cell cycledependent recruitment of telomerase RNA and Cajal bodies to human telomeres. Mol. Biol. Cell 17: 944

Jones K.W., Gorzynski K., Hales C.M., Fischer U., Badbanchi F., Terns R.M., and Terns M.P. 2001. Direct interaction of the spinal muscular atrophy disease protein SMN with the small nucleolar RNA-associated protein fibrillarin. J. Biol. Chem. 276: 38645.

King T.H., Decatur W.A., Bertrand E., Maxwell E.S., and Fournier M.J. 2001. A well-connected and conserved nucleoplasmic helicase is required for production of box $\mathrm{C} / \mathrm{D}$ and H/ACA snoRNAs and localization of snoRNP proteins. Mol. Cell. Biol. 21: 7731 .

Kiss T. 2001. Small nucleolar RNA-guided post-transcriptional modification of cellular RNAs. EMBO J. 20: 3617.

Kiss T. and Filipowicz W. 1993. Small nucleolar RNAs encoded by introns of the human cell cycle regulatory gene RCC1. EMBO J. 12: 2913.

1995. Exonucleolytic processing of small nucleolar RNAs from pre-mRNA introns. Genes Dev. 9: 1411.

Kiss T., Bortolin M.L., and Filipowicz W. 1996. Characterization of the intron-encoded U19 RNA, a new mammalian small nucleolar RNA that is not associated with fibrillarin. Mol. Cell. Biol. 16: 1391.

Kiss A.M., Jády B.E., Bertrand E., and Kiss T. 2004. Human box H/ACA pseudouridylation guide RNA machinery. Mol. Cell. Biol. 24: 5797.

Kiss A.M., Jády B.E., Darzacq X., Verheggen C., Bertrand E., and Kiss T. 2002. A Cajal body-specific pseudouridylation guide RNA is composed of two box H/ACA snoRNA-like domains. Nucleic Acids Res. 30: 4643.

Kiss-László Z., Henry Y., and Kiss T. 1998. Sequence and structural elements of methylation guide snoRNAs essential for sitespecific ribose methylation of pre-rRNA. EMBO J. 17: 797. 
Kiss-László Z., Henry Y., Bachellerie J.P., Caizergues-Ferrer M., and Kiss T. 1996. Site-specific ribose methylation of preribosomal RNA: A novel function for small nucleolar RNAs. Cell 85: 1077.

Klein D.J., Schmeing T.M., Moore P.B., and Steitz T.A. 2001. The kink-turn: A new RNA secondary structure motif. EMBO J. 20: 4214

Lafontaine D.L. and Tollervey D. 1999. Nop58p is a common component of the box $\mathrm{C}+\mathrm{D}$ snoRNPs that is required for snoRNA stability. RNA 5: 455.

Lange T.S., Borovjagin A., Maxwell E.S., and Gerbi S.A. 1998. Conserved boxes $\mathrm{C}$ and $\mathrm{D}$ are essential nucleolar localization elements of U14 and U8 snoRNAs. EMBO J. 17: 3176.

Lange T.S., Ezrokhi M., Amaldi F., and Gerbi S.A. 1999. Box H and box ACA are nucleolar localization elements of U17 small nucleolar RNA. Mol. Biol. Cell 10: 3877.

Lestrade L. and Weber M.J. 2006. snoRNA-LBME-db, a comprehensive database of human H/ACA and C/D box snoRNAs. Nucleic Acids Res. 34: D158.

Leverette R.D., Andrews M.T., and Maxwell E.S. 1992. Mouse U14 snRNA is a processed intron of the cognate hsc70 heat shock pre-messenger RNA. Cell 71: 1215.

Lukowiak A.A., Narayanan A., Li Z.H., Terns R.M., and Terns M.P. 2001. The snoRNA domain of vertebrate telomerase RNA functions to localize the RNA within the nucleus. RNA 7: 1833.

Lyman S.K., Gerace L., and Baserga S.J. 1999. Human Nop5/Nop58 is a component common to the box C/D small nucleolar ribonucleoproteins. RNA 5: 1597.

Maraia R.J. and Bayfield M.A. 2006. The La protein-RNA complex surfaces. Mol. Cell 21: 149.

Martin-Rivera L. and Blasco M.A. 2001. Identification of functional domains and dominant negative mutations in vertebrate telomerase RNA using an in vivo reconstitution system. $J$. Biol. Chem. 276: 5856.

Massenet S., Mougin A., and Branlant C. 1998. Posttranscriptional modification in the $\mathrm{U}$ small nuclear RNAs. In Modification and editing of RNA (ed. H. Grosjean and R. Benne), p. 201. ASM Press, Washington D.C.

Meier U.T. 2005. The many facets of H/ACA ribonucleoproteins. Chromosoma 114: 1.

Meier U.T. and Blobel G. 1994. NAP57, a mammalian nucleolar protein with a putative homolog in yeast and bacteria. $J$. Cell Biol. 127: 1505.

Mitchell J.R. and Collins K. 2000. Human telomerase activation requires two independent interactions between telomerase RNA and telomerase reverse transcriptase. Mol. Cell 6: 361.

Mitchell J.R., Cheng J., and Collins K. 1999. A box H/ACA small nucleolar RNA-like domain at the human telomerase RNA 3' end. Mol. Cell. Biol. 19: 567.

Mouaikel J., Verheggen C., Bertrand E., Tazi J., and Bordonne R. 2002. Hypermethylation of the cap structure of both yeast snRNAs and snoRNAs requires a conserved methyltransferase that is localized to the nucleolus. Mol. Cell 9: 891 .

Narayanan A., Speckmann W., Terns R., and Terns M.P. 1999a. Role of the box C/D motif in localization of small nucleolar RNAs to coiled bodies and nucleoli. Mol. Biol. Cell 10: 2131.

Narayanan A., Lukowiak A., Jády B.E., Dragon F., Kiss T., Terns R.M., and Terns M.P. 1999b. Nucleolar localization signals of box H/ACA small nucleolar RNAs. EMBO J. 18: 5120 .

Newman D.R., Kuhn J.F., Shanab G.M., and Maxwell E.S. 2000. Box C/D snoRNA-associated proteins: Two pairs of evolutionarily ancient proteins and possible links to replication and transcription. RNA 6: 861 .

Ni J., Tien A.L., and Fournier M.J. 1997. Small nucleolar RNAs direct site-specific synthesis of pseudouridine in ribosomal RNA. Cell 89: 565.

Ogg S.C. and Lamond A.I. 2002. Cajal bodies and coilinMoving towards function. J. Cell Biol. 159: 17.

Ohno M., Segref A., Kuersten S., and Mattaj I.W. 2002. Identity elements used in export of mRNAs. Mol. Cell 9: 659.

Omer A.D., Ziesche S., Decatur W.A., Fournier M.J., and Dennis P.P. 2003. RNA-modifying machines in archaea. Mol. Microbiol. 48: 617.
Ooi S.L., Samarsky D.A., Fournier M.J., and Boeke J.D. 1998. Intronic snoRNA biosynthesis in Saccharomyces cerevisiae depends on the lariat-debranching enzyme: Intron length effects and activity of a precursor snoRNA. RNA 4: 1096.

Padgett R.A., Grabowski P.J., Konarska M.M., Seiler S., and Sharp P.A. 1986. Splicing of messenger RNA precursors. Annu. Rev. Biochem. 55: 1119.

Paushkin S., Gubitz A.K., Massenet S., and Dreyfuss G. 2002. The SMN complex, an assemblyosome of ribonucleoproteins. Curr. Opin. Cell Biol. 14: 305.

Pellizzoni L., Baccon J., Charroux B., and Dreyfuss G. 2001. The survival of motor neurons (SMN) protein interacts with the snoRNP proteins fibrillarin and GAR1. Curr. Biol. 11: 1079.

Perumal K. and Reddy R. 2002. The 3' end formation in small RNAs. Gene Expr. 10: 59.

Platani M., Goldberg I., Lamond A.I., and Swedlow J.R. 2002. Cajal body dynamics and association with chromatin are ATP-dependent. Nat. Cell Biol. 4: 502.

Platani M., Goldberg I., Swedlow J.R., and Lamond A.I. 2000. In vivo analysis of Cajal body movement, separation, and joining in live human cells. J. Cell Biol. 151: 1561.

Reddy R., Li W.Y., Henning D., Choi Y.C., Nohga K., and Busch H. 1981. Characterization and subcellular localization of 7-8 S RNAs of Novikoff hepatoma. J. Biol. Chem. 256: 8452.

Richard P., Kiss A.M., Darzacq X., and Kiss T. 2006. Cotranscriptional recognition of human intronic box H/ACA snoRNAs occurs in a splicing-independent manner. Mol. Cell. Biol. 26: 2540.

Richard P., Darzacq X., Bertrand E., Jády B.E., Verheggen C., and Kiss T. 2003. A common sequence motif determines the Cajal body-specific localisation of box H/ACA scaRNAs. EMBO J. 22: 4283

Ruff E.A., Rimoldi O.J., Raghu B., and Eliceiri G.L. 1993. Three small nucleolar RNAs of unique nucleotide sequences. Proc. Natl. Acad. Sci. 90: 635.

Samarsky D.A., Fournier M.J., Singer R.H., and Bertrand E. 1998. The snoRNA box C/D motif directs nucleolar targeting and also couples snoRNA synthesis and localization. EMBO J. 17: 3747 .

Schattner P., Barberan-Soler S., and Lowe T.M. 2006. A computational screen for mammalian pseudouridylation guide H/ACA RNAs. RNA 12: 15.

Schimmang T., Tollervey D., Kern H., Frank R., and Hurt E.C. 1989. A yeast nucleolar protein related to mammalian fibrillarin is associated with small nucleolar RNA and is essential for viability. EMBO J. 8: 4015.

Shaw P.J., Beven A.F., Leader D.J., and Brown J.W. 1998. Localization and processing from a polycistronic precursor of novel snoRNAs in maize. J. Cell Sci. 111: 2121.

Sleeman J.E. and Lamond A.I. 1999. Newly assembled snRNPs associate with coiled bodies before speckles, suggesting a nuclear snRNP maturation pathway. Curr. Biol. 9: 1065.

Szewczak L.B., DeGregorio S.J., Strobel S.A., and Steitz J.A. 2002. Exclusive interaction of the $15.5 \mathrm{kD}$ protein with the terminal box $\mathrm{C} / \mathrm{D}$ motif of a methylation guide snoRNP. Chem. Biol. 9: 1095.

Szewczak L.B., Gabrielsen J.S., Degregorio S.J., Strobel S.A., and Steitz J.A. 2005. Molecular basis for RNA kink-turn recognition by the h15.5K small RNP protein. RNA 11: 1407.

Teixeira M.T., Arneric M., Sperisen P., and Lingner J. 2004. Telomere length homeostasis is achieved via a switch between telomerase- extendible and -nonextendible states. Cell 117: 323.

Ten Hagen K.G., Gilbert D.M., Willard H.F., and Cohen S.N. 1990. Replication timing of DNA sequences associated with human centromeres and telomeres. Mol. Cell. Biol. 10: 6348.

Terns M.P. and Dahlberg J.E. 1994. Retention and 5' cap trimethylation of U3 snRNA in the nucleus. Science 264: 959.

Terns M.P. and Terns R.M. 2001. Macromolecular complexes: SMN-The master assembler. Curr. Biol. 11: R862.

. 2002. Small nucleolar RNAs: Versatile trans-acting molecules of ancient evolutionary origin. Gene Expr. 10: 17. 
Terns M.P., Grimm C., Lund E., and Dahlberg J.E. 1995. A common maturation pathway for small nucleolar RNAs. EMBOJ. 14: 4860

Tomlinson R.L., Ziegler T.D., Supakorndej T., Terns R.M., and Terns M.P. 2006. Cell cycle-regulated trafficking of human telomerase to telomeres. Mol. Biol. Cell 17: 955.

Tran E., Brown J., and Maxwell E.S. 2004. Evolutionary origins of the RNA-guided nucleotide-modification complexes: From the primitive translation apparatus? Trends Biochem. Sci. 29: 343

Tyc K. and Steitz J.A. 1989. U3, U8 and U13 comprise a new class of mammalian snRNPs localized in the cell nucleolus. EMBO J. 8: 3113

Tycowski K.T., Aab A., and Steitz J.A. 2004. Guide RNAs with $5^{\prime}$ caps and novel box C/D snoRNA-like domains for modification of snRNAs in metazoa. Curr. Biol. 14: 1985.

Tycowski K.T., Shu M.D., and Steitz J.A. 1993. A small nucleolar RNA is processed from an intron of the human gene encoding ribosomal protein S3. Genes Dev. 7: 1176

Vasiljeva L. and Buratowski S. 2006. Nrd1 interacts with the nuclear exosome for 3' processing of RNA polymerase II transcripts. Mol. Cell 21: 239.

Verheggen C., Lafontaine D.L., Samarsky D., Mouaikel J., Blanchard J.M., Bordonne R., and Bertrand E. 2002. Mammalian and yeast U3 snoRNPs are matured in specific and related nuclear compartments. EMBO J. 21: 2736.

Verheggen C., Mouaikel J., Thiry M., Blanchard J.M., Tollervey D., Bordonne R., Lafontaine D.L., and Bertrand E. 2001. Box C/D small nucleolar RNA trafficking involves small nucleolar RNP proteins, nucleolar factors and a novel nuclear domain. EMBO J. 20: 5480.

Vidovic I., Nottrott S., Hartmuth K., Luhrmann R., and Ficner R. 2000 . Crystal structure of the spliceosomal $15.5 \mathrm{kD}$ protein bound to a U4 snRNA fragment. Mol. Cell 6: 1331.

Wang C. and Meier U.T. 2004. Architecture and assembly of mammalian H/ACA small nucleolar and telomerase ribonucleoproteins. EMBO J. 23: 1857.

Wang C., Query C.C., and Meier U.T. 2002. Immunopurified small nucleolar ribonucleoprotein particles pseudouridylate rRNA independently of their association with phosphorylated Nopp140. Mol. Cell. Biol. 22: 8457.

Wang H., Boisvert D., Kim K.K., Kim R., and Kim S.H. 2000. Crystal structure of a fibrillarin homologue from Methanococcus jannaschii, a hyperthermophile, at $1.6 \AA$ resolution. EMBO J. 19: 317.

Watkins N.J., Dickmanns A., and Luhrmann R. 2002. Conserved stem II of the box C/D motif is essential for nucleolar localization and is required, along with the $15.5 \mathrm{~K}$ protein, for the hierarchical assembly of the box C/D snoRNP. Mol. Cell. Biol. 22: 8342

Watkins N.J., Leverette R.D., Xia L., Andrews M.T., and Maxwell E.S. 1996. Elements essential for processing intronic U14 snoRNA are located at the termini of the mature snoRNA sequence and include conserved nucleotide boxes $\mathrm{C}$ and D. RNA 2: 118.

Watkins N.J., Gottschalk A., Neubauer G., Kastner B., Fabrizio P., Mann M., and Luhrmann R. 1998. Cbf5p, a potential pseudouridine synthase, and Nhp2p, a putative RNA-binding protein, are present together with Garlp in all $\mathrm{H}$ BOX/ACA-motif snoRNPs and constitute a common bipartite structure. RNA 4: 1549.

Watkins N.J., Lemm I., Ingelfinger D., Schneider C., Hossbach M., Urlaub H., and Luhrmann R. 2004. Assembly and maturation of the U3 snoRNP in the nucleoplasm in a large dynamic multiprotein complex. Mol. Cell 16: 789.

Watkins N.J., Segault V., Charpentier B., Nottrott S., Fabrizio P., Bachi A., Wilm M., Rosbash M., Branlant C., and Luhrmann R. 2000. A common core RNP structure shared between the small nucleoar box C/D RNPs and the spliceosomal U4 snRNP. Cell 103: 457.

Wolin S.L. and Cedervall T. 2002. The La protein. Annu. Rev. Biochem. 71: 375.

Wright W.E., Tesmer V.M., Liao M.L., and Shay J.W. 1999. Normal human telomeres are not late replicating. Exp. Cell Res. 251: 492.

Wu P., Brockenbrough J.S., Metcalfe A.C., Chen S., and Aris J.P. 1998. Nop5p is a small nucleolar ribonucleoprotein component required for pre-18 S rRNA processing in yeast. $J$. Biol. Chem. 273: 16453.

Yang P.K., Rotondo G., Porras T., Legrain P., and Chanfreau G. 2002. The Shq1p.Naf1p complex is required for box H/ACA small nucleolar ribonucleoprotein particle biogenesis. J. Biol. Chem. 277: 45235 .

Yang P.K., Hoareau C., Froment C., Monsarrat B., Henry Y., and Chanfreau G. 2005. Cotranscriptional recruitment of the pseudouridylsynthetase Cbf5p and of the RNA binding protein Naflp during H/ACA snoRNP assembly. Mol. Cell. Biol. 25: 3295

Yang Y., Isaac C., Wang C., Dragon F., Pogacic V., and Meier U.T. 2000. Conserved composition of mammalian box H/ACA and box C/D small nucleolar ribonucleoprotein particles and their interaction with the common factor Nopp140. Mol. Biol. Cell 11: 567.

Yong J., Wan L., and Dreyfuss G. 2004. Why do cells need an assembly machine for RNA-protein complexes? Trends Cell Biol. 14: 226.

Yu Y.-T., Scharl E.C., Smith C.M., and Steitz J.A. 1999. The growing world of small nuclear ribonucleoproteins. In The RNA world, 2nd edition (ed. R.F. Gesteland et al.), p. 487. Cold Spring Harbor Laboratory Press, Cold Spring Harbor, New York.

Zhu Y., Tomlinson R.L., Lukowiak A.A., Terns R.M., and Terns M.P. 2004. Telomerase RNA accumulates in Cajal bodies in human cancer cells. Mol. Biol. Cell 15: 81. 


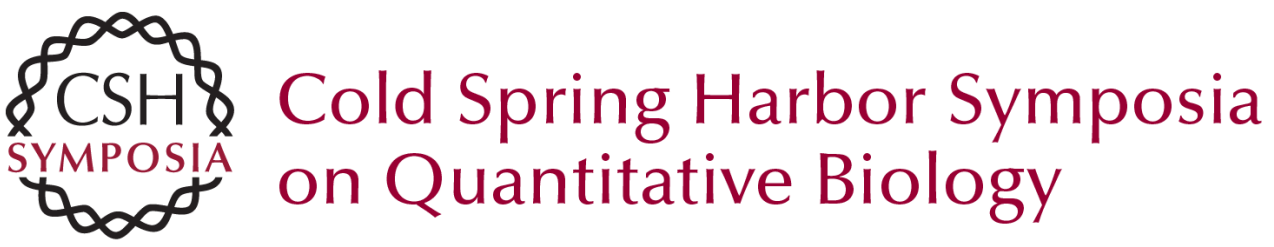

\section{Biogenesis and Intranuclear Trafficking of Human Box C/D and H/ACA RNPs}

T. KISS, E. FAYET, B.E. JÁDY, et al.

Cold Spring Harb Symp Quant Biol 2006 71: 407-417

Access the most recent version at doi:10.1101/sqb.2006.71.025

References This article cites 127 articles, 67 of which can be accessed free at: http://symposium.cshlp.org/content/71/407.full.html\#ref-list-1

License

Email Alerting Receive free email alerts when new articles cite this article - sign up in Service the box at the top right corner of the article or click here. 